University of Nebraska - Lincoln

DigitalCommons@University of Nebraska - Lincoln

Quercetin up-regulates paraoxonase 1 gene expression via sterol regulatory element binding protein 2 that translocates from the endoplasmic reticulum to the nucleus where it specifically interacts with sterol responsive element-like sequence in paraoxonase 1 promoter in HuH7 liver cells

\author{
Mamatha Garige \\ The George Washington University \\ Maokai Gong \\ The George Washington University \\ Ravi Varatharajalu \\ The George Washington University \\ M. Raj Lakshman \\ Veterans Affairs Medical Center, raj.lakshman@va.gov
}

Follow this and additional works at: https://digitalcommons.unl.edu/veterans

Garige, Mamatha; Gong, Maokai; Varatharajalu, Ravi; and Lakshman, M. Raj, "Quercetin up-regulates paraoxonase 1 gene expression via sterol regulatory element binding protein 2 that translocates from the endoplasmic reticulum to the nucleus where it specifically interacts with sterol responsive element-like sequence in paraoxonase 1 promoter in HuH7 liver cells" (2010). U.S. Department of Veterans Affairs Staff Publications. 37.

https://digitalcommons.unl.edu/veterans/37

This Article is brought to you for free and open access by the U.S. Department of Veterans Affairs at DigitalCommons@University of Nebraska - Lincoln. It has been accepted for inclusion in U.S. Department of Veterans Affairs Staff Publications by an authorized administrator of DigitalCommons@University of Nebraska - Lincoln. 


\title{
Quercetin up-regulates paraoxonase 1 gene expression via sterol regulatory element binding protein 2 that translocates from the endoplasmic reticulum to the nucleus where it specifically interacts with sterol responsive element-like sequence in paraoxonase 1 promoter in $\mathrm{HuH7}$ liver cells
}

\author{
Mamatha Garige $^{\mathrm{a}}$, Maokai Gong ${ }^{\mathrm{a}}$, Ravi Varatharajalu ${ }^{\mathrm{a}}$, M. Raj Lakshman ${ }^{\mathrm{b}, *}$ \\ ${ }^{a}$ Department of Biochemistry, Molecular Biology and Medicine, The George Washington University, NW, Washington, DC 20052, USA \\ ${ }^{\mathrm{b}}$ The Lipid Research Laboratory 151-T, Veterans Affairs Medical Center, NW, Washington, DC 20422, USA
}

Received 18 September 2009; accepted 23 December 2009

\begin{abstract}
We previously showed that quercetin expresses its antiatherogenic effects by up-regulating paraoxonase 1 (PON1) gene and high-density lipoprotein's protective capacity against low-density lipoprotein oxidation. In an attempt to elucidate the mechanism of action of quercetin, we have now determined the effects of quercetin on PON1 gene expression, activity, protein level, nuclear mature sterol regulatory element binding protein 2 (SREBP2) level, and its translocation from the endoplasmic reticulum to nucleus and its interaction with PON1 promoter in human $\mathrm{HuH7}$ liver cells using real-time reverse transcriptase polymerase chain reaction, spectrophotometry, immunoblot, confocal microscopy, and electrophoretic mobility shift assay techniques, respectively. Quercetin $(20 \mu \mathrm{mol} / \mathrm{L})$ treatment increased PON1 messenger RNA by $75 \%(P<.02)$, with a concomitant 2 -fold $(P<.05)$ increase in PON1 activity accompanied by $60 \%(P<.01)$ increase in PON1 protein level. There was parallel to the 1.5 - to 2.0 -fold increase $(P<.05)$ in mature SREBP2 in the cell nuclei that was verified by increased immunolocalization of the mature SREBP2 (65-kd species) in the nuclei of quercetin-treated cells by confocal microscopy. Evaluation of the binding of biotin-labeled sterol responsive element (SRE)-like element of the PON1 promoter to the nuclear extract from the 24-hour quercetin $(20 \mu \mathrm{mol} / \mathrm{L})$-treated HuH7 cells by electrophoretic mobility shift assay revealed that the SREBP2 specifically binds to the SRElike element that was abolished by prior incubation with anti-SREBP2 or significantly decreased by 200-fold molar excess of unlabeled SRElike sequence. Based on these results, we conclude that quercetin exhibits its antiatherogenic property by eliciting the translocation of the mature SREBP2 from endoplasmic reticulum to the nucleus, where it binds to SRE-like sequence in the PON1 promoter and up-regulates PON1 gene transcription and PON1 activity.

(C) 2010 Published by Elsevier Inc.
\end{abstract}

\section{Introduction}

Paraoxonase 1 (PON1) is a calcium-dependent phosphotriesterase tightly associated with high-density lipoprotein particles $[1,2]$. Experimental evidences have shown that PON1 functions as an antioxidative enzyme that inhibits the oxidation of low-density lipoprotein (LDL) [3-5] that prevents the development of atherosclerosis $[6,7]$. It also hydrolyzes homocysteine thiolactone to homocysteine,

\footnotetext{
* Corresponding author. Tel.: +1 202745 8330; fax: +1 2024622006

E-mail address: raj.lakshman@va.gov (M.R. Lakshman).
}

which alters the proteins in the arterial wall [8]. Paraoxonase 1 knockout mice are more susceptible to atherosclerosis than wild-type littermates, and clinical studies have linked the PON1 to the prevention of cardiovascular disease $[9,10]$.

Sterol regulatory element binding proteins (SREBPs) are a new class of membrane-bound transcription factors that modulate lipid homeostasis [11]. Currently, 3 types of SREBPs exist, namely, SREBP1a, SREBP1c, and SREBP2. Whereas SREBP1a and SREBP1c control fatty acid pathway, SREBP2 regulates cholesterol biosynthetic pathway. Sterol regulatory element binding protein 1a and SREBP2 are present in most cultured cell lines, whereas SREBP1c and SREBP2 are present in liver and other tissues. 
Newly synthesized SREBP is inserted into the endoplasmic reticulum (ER) as an inactive protein. When the cellular cholesterol is low, SREBP is escorted into the Golgi by SREBP cleavage activating protein where it is proteolytically cleaved by specific proteases $\mathrm{S} 1 \mathrm{P}$ and $\mathrm{S} 2 \mathrm{P}$ in a 2-step process to yield the mature SREBP that is translocated into the nucleus, where it activates transcription by binding to specific sterol responsive elements (SREs) in the promoter/ enhancer regions of multiple target genes.

Recent studies have shown conflicting results with regard to the action of statins and flavones in the regulation of PON1 gene [12-14]. Thus, whereas simvastatin [12] and soy isoflavones [13] have been reported to modulate PON1 gene via SREBP2, Gouedard et al [14] reported the opposite effects by statins. Subsequently, the same group [15] came to the conclusion that polyphenols regulate PON1 expression via the aryl hydrocarbon receptor. However, a more recent study indicates that pomegranate polyphenols regulate PON1 expression via peroxisome proliferator-activated receptor- $\gamma$ pathway [16].

Quercetin, a ubiquitous flavonoid present in fruits and vegetables, reduces LDL oxidation [17,18] presumably because of its free radical-scavenging property and has beneficial effects with respect to cardiovascular disease and certain cancers [19]. We have recently shown that quercetin supplementation in rats up-regulates liver PON1 expression with associated inhibition of LDL oxidation [20]. In the present study, we have demonstrated in $\mathrm{HuH7}$ cells that quercetin up-regulates not only PON1 expression with associated increased PON1 promoter activity in SREdependent manner, but also its protein content and activity in a dose-dependent manner within 24 hours of exposure accompanied by concomitant increase in the nuclear mature SREBP2 that specifically binds to the SRE-like sequence in the PON1 promoter.

\section{Experimental procedures}

\subsection{HuH7 cell culture}

The human HuH7 liver cell line (a gift from Dr Terence Donohue and Dr Natalia Osna, University of Nebraska Medical Center, Omaha, NE) was maintained at $37^{\circ} \mathrm{C}$ in an atmosphere containing $5 \% \mathrm{CO}_{2}$ and cultivated in Dulbecco modified Eagle medium, which was supplemented with heat inactivated $10 \%$ fetal bovine serum, 1\% L-glutamine, and $1 \%$ penicillin/streptomycin. $\mathrm{HuH} 7$ cells were plated at $70 \%$ confluence and incubated with 0 to $20 \mu \mathrm{mol} / \mathrm{L}$ quercetin in $0.1 \%$ (vol/vol) dimethyl sulfoxide (DMSO) for either 24 or 48 hours. The control cells were exposed to $0.1 \%$ (vol $/ \mathrm{vol}$ ) DMSO solvent vehicle alone.

\subsection{RNA isolation}

Replicate cultures of HuH7 cells were incubated in the absence and presence of 10 and $20 \mu \mathrm{mol} / \mathrm{L}$ quercetin under standard conditions for 48 hours. The total RNA was isolated from cell cultures using the Tri-Reagent (Molecular Research Center, Cincinnati, OH) following the manufacturer's instructions. Total RNA concentrations were measured by absorbance reading at $260 \mathrm{~nm}$ using SpectroMAX 190 (Molecular Devices, Sunnyvale, CA). The purity and concentration of total RNA samples were examined by determining the $\mathrm{AB}_{260 \mathrm{~B}} / \mathrm{AB}_{280 \mathrm{~B}}$ ratio. Isolated RNA was used immediately or stored at $-80^{\circ} \mathrm{C}$ until use.

\subsection{Real-time polymerase chain reaction}

The method was essentially as described by us previously [20]. Briefly, complementary DNA templates for use in realtime polymerase chain reaction (PCR) were synthesized from $5 \mu \mathrm{g}$ of total RNA by in vitro transcription in $20-\mu \mathrm{L}$ reaction containing $0.5 \mu \mathrm{g}$ Oligo (dT), $10 \mu \mathrm{mol} / \mathrm{L}$ dNTPs, and $1 \mu \mathrm{L}$ of Superscript II reverse transcriptase (Invitrogen, Carlsbad, CA) at $42^{\circ} \mathrm{C}$ for 50 minutes. Typical real-time PCR reaction mixture included the same amount of complementary DNA templates from RT, 10 pmol of each primer, $25 \mu \mathrm{L}$ iQ SYBR Green Supermix (Bio-Rad, Hercules, CA), and sterile water in a reaction volume of 50 $\mu \mathrm{L}$. The PCR conditions were as follows: 3 minutes at $95^{\circ} \mathrm{C}$ followed by 40 cycles at $95^{\circ} \mathrm{C}$ for 30 seconds, $55^{\circ} \mathrm{C}$ for 30 seconds, and $68^{\circ} \mathrm{C}$ for 1 minute. The primer pairs for human PON1 are:

\section{Forward primer: $5^{\prime}$-CTGCTGATTGGCACAGTGTT- $3^{\prime}$}

Reverse primer: 5'-GGGTCAGCATTCATTGTTCA-3'.

This primer pair was first tested by regular PCR to be highly effective and specific for amplification. $\beta$-Actin (Ambion) was used as the housekeeping gene. Relative PON1 gene expression level was calculated by subtracting the threshold cycle number $(\mathrm{Ct})$ of the $\beta$-actin gene from the $\mathrm{Ct}$ of PON1 and raising 2 to the power of this difference. $C t$ value is defined as the number of PCR cycles at which the fluorescent signal during the PCR reaches a fixed threshold for each sample.

\subsection{PON1 activity measurement}

For experiments to measure the influence of quercetin on PON1 activity, we used $5 \times 10^{6}$ cells in $75-\mathrm{cm}^{2}$ flasks. Replicate cultures of $\mathrm{HuH} 7$ cells were incubated in the absence and presence of 10 and $20 \mu \mathrm{mol} / \mathrm{L}$ quercetin under standard conditions for 48 hours. At the end of the incubation period, the cells were washed, harvested, and homogenized in $50 \mathrm{mmol} / \mathrm{L}$ glycine: $\mathrm{NaOH}$ buffer, $\mathrm{pH}$ 10.5. A suitable aliquot of each lysate was incubated with $1 \mathrm{mmol} / \mathrm{L}$ paraoxon in the presence of $2 \mathrm{mmol} / \mathrm{L} \mathrm{CaCl} 2$ at $37^{\circ} \mathrm{C}$ for 15 minutes. The extent of 4-nitrophenol formed was measured based on the extinction coefficient of 18290 $(\mathrm{mol} / \mathrm{L})^{-1} \mathrm{~cm}^{-1}$ for 4-nitrophenol [5]. The PON1 activity is expressed as nanomoles of paraoxon hydrolyzed per hour per milligram cell lysate. 


\subsection{Sodium dodecyl sulfate polyacrylamide gel electrophoresis and Western blot analyses}

$\mathrm{HuH} 7$ cells were incubated with $0.1 \%$ DMSO (vol/vol) alone or indicated concentrations of quercetin for 24 and 48 hours, after which the total cell and nuclear fractions were extracted by NE-PER Nuclear and Cytoplasmic Extraction Reagent (Pierce, Rockford, IL) containing protease inhibitors (Roche, Indianapolis, IN) according to the manufacturer's protocol. The total cell extract was electrophoretically resolved in $4 \%$ to $15 \%$ denaturing polyacrylamide gel (PAGE) and immunoblotted using antibodies against PON1 (Abcam, Cambridge, MA) and actin (Santa Cruz Biotech, Santa Cruz, CA). Similarly, the nuclear extract was electrophoretically resolved by PAGE and immunoblotted using antibodies against SREBP2 and LaminB1 (Abcam). The proteins were visualized by enhanced chemiluminescence using reagents from Perkin Elmer (Waltham, MA), and the intensity of each band was quantified using a Fluorchem 8800 densitometer (Alpha Innotech, San Leandro, CA).

\subsection{Immunohistochemistry for SREBP2 using confocal microscope}

HuH7 cells were grown in 2 chamber slides and treated with and without $20 \mu \mathrm{mol} / \mathrm{L}$ quercetin for 24 hours. At the end of the incubation period, the cells were washed in $1 \times$ phosphate-buffered saline (PBS) for 3 times followed by fixation in $4 \%$ formaldehyde solution in $1 \times$ PBS $(\mathrm{pH}$ 7.4) for 15 minutes and then permeabilized with $4 \%$ formaldehyde solution in $0.2 \%$ (vol/vol) Triton X-100 in $1 \times$ PBS (pH 7.4) for another 10 minutes. After blocking with $10 \%(\mathrm{vol} / \mathrm{vol})$ normal donkey serum in $1 \times \mathrm{PBS}(\mathrm{pH}$ 7.4) for 1 hour at RT, the cells were incubated overnight $\left(4^{\circ} \mathrm{C}\right)$ with primary rabbit anti-human-SREBP2 (Abcam, at 1:100 dilution) antibody. A control chamber in each slide was not treated with primary antibody to account for background fluorescence. All the cells were then incubated for 1 hour with donkey anti-rabbit immunoglobulin $G$ Alexa 488 secondary antibody (all dilutions 1:200) in the dark. The cells were then washed 3 times with PBS for 5 minutes in the dark and were incubated with TOPRO for 1 minute to label the cell nuclei, and then rinsed with $1 \times$ PBS. The slides were then mounted with a cover glass and analyzed using a confocal microscope equipped with Nikon Eclipse TE300 inverted microscope (Bio-Rad Laser Radiance 2000).

\subsection{Electrophoretic mobility shift assay}

Electrophoretic mobility shift assay (EMSA) was carried out to quantify the binding of nuclear SREBP2 to SRE core sequence $5^{\prime}$-ATCACCCCAC- $3^{\prime}$ and SRE-like sequence $5^{\prime}$ ATCAAGCTAC-3' ( -392 to -382 base pairs [bp]) present in the $5^{\prime}$ promoter region of PON1 gene. A nonradioactive method where the $3^{\prime}$ end of the probe was labeled with biotin was used for these experiments (Biotin 3' End DNA Labeling Kit, Pierce). The binding reaction was carried out for 20 minutes at room temperature in the presence of $50 \mathrm{ng} / \mu \mathrm{L}$ poly $(\mathrm{dI}-\mathrm{dC})$, $0.05 \%$ Nonidet P- $40,5 \mathrm{mmol} / \mathrm{L} \mathrm{MgCl} 2,10 \mathrm{mmol} / \mathrm{L}$ EDTA, and $2.5 \%$ glycerol in $1 \times$ binding buffer (LightShift Chemiluminescent EMSA Kit, Pierce) using 20 fmol of biotin-end-labeled target DNA and $4 \mu \mathrm{g}$ of the nuclear extract from 24-hour quercetin $(20 \mu \mathrm{mol} / \mathrm{L})$-treated cells. For competitive assays, the nuclear extract was first incubated with either unlabeled SRElike element ( $4 \mathrm{pmol})$ or $3 \mu \mathrm{L}$ of anti-SREBP2 antibody (Abcam) before the binding reaction was carried out. The reaction mixture was loaded onto the native $4 \%$ polyacrylamide gel that was preelectrophoresed for 30 minutes in $0.5 \times$ Trisborate-EDTA (TBE) followed by electrophoresis for 60 minutes at $100 \mathrm{~V}$ and then electrophoretically transferred onto a positively charged nylon membrane (Hybond-N+) in $0.5 \times$ $\mathrm{TBE}$ at $100 \mathrm{~V}$ for 30 minutes. The membrane was cross-linked at $120 \mathrm{~mJ} / \mathrm{cm}^{2}$. The DNA-protein complex was visualized with horseradish peroxidase-conjugated streptavidin (LightShift Chemiluminescent EMSA Kit, Pierce) according to the manufacturer's instructions.

\subsection{Determination of PON1 polymorphism}

The genotyping of the HuH7 cell line with respect to PON1 polymorphism was assessed according to the methods of Humbert et al [21] and Garin et al [22]. Briefly, the DNA was extracted from the cell line using the DNA Purification Kit (Qiagen Science, MD). Allele-specific primers described by Humbert et al [21] to encompass the polymorphism affecting position 192 were used to amplify the polymorphic region of the gene. The PCR contained approximately 100 to $500 \mathrm{ng}$ DNA template, $0.1 \mu \mathrm{mol} / \mathrm{L}$ of each primer, $0.2 \mathrm{mmol} / \mathrm{L}$ of the 4 deoxynucleotide triphosphates (dNTPs), 1 unit of high-fidelity Taq DNA polymerase, and $1.5 \mathrm{mmol} / \mathrm{L} \mathrm{MgCl}_{2}$. The DNA was amplified in a PCR machine for 30 to 35 cycles. The PCR optimal temperature and times were as follows: denaturation at $94^{\circ} \mathrm{C}$ for 1 minute, annealing at $61^{\circ} \mathrm{C}$ for 1 minute, and extension at $68^{\circ} \mathrm{C}$ for 1 minute, with a final extension for 5 minutes. The nucleotide substitution corresponding to position $192(\mathrm{Gln} \rightarrow \mathrm{Arg})$ creates an Alwl restriction site. Allele Q (glutamine) corresponded to a 99-bp fragment, whereas allele R (arginine) corresponded to 65- and 34-bp fragments. The PCR product was restriction digested using Alwl (New England Biolabs, Beverly, MA) at $37^{\circ} \mathrm{C}$ for 3 hours. The digested products were analyzed on a $3.5 \%$ agarose gel cast and run in $1 \times$ TBE buffer.

\subsection{Statistical analysis}

Data are presented as the mean $\pm \mathrm{SD}$. All the values in various experimental groups were normalized such that the mean of the control group was taken as 1. Statistical significance was determined by analysis of variance followed by Tukey test. 


\section{Results}

\subsection{Effect of quercetin concentration on PON1 activity and protein level}

Initially, we genotyped the PON1 isoform in $\mathrm{HuH7}$ cells with respect to polymorphism at amino acid 192 because alterations in this allele are known to affect PON1 activity with paraoxon as the substrate [21]. Thus, the HuH7 cell line we have used in this study was characterized to be the RQ192 isoform (data not shown). We then tested the concentration effect of quercetin on the cellular activity of PON1 and its protein level. As shown in Fig. 1A, cellular PON1 activity increased from basal activity in a dosedependent manner with increasing concentration of quercetin in the culture medium. Thus, the cellular PON 1 activity was increased up to 2 -fold $(P<.05)$, with a concomitant $60 \%$ $(P<.01)$ increase in the cellular PON1 protein (Fig. 1B) at $20 \mu \mathrm{mol} / \mathrm{L}$ quercetin concentration.

\subsection{Effect of quercetin on the PON1 gene expression}

To investigate whether the increase in PON1 activity and protective effect of PON1 caused by quercetin correlated with a concomitant up-regulation of its gene, real-time reverse transcriptase PCR was performed on total RNA samples prepared from $\mathrm{HuH} 7$ cells treated for 48 hours without and with increasing concentrations of quercetin. The results are shown in Fig. 2. There was a progressive up-regulation of PON1 messenger RNA (mRNA) expression with increasing quercetin concentration. Thus, PON1 mRNA increased up to $75 \%(P<.02)$ at $20 \mu \mathrm{mol} / \mathrm{L}$ quercetin (Fig. 2$)$.

\subsection{Up-regulation of PON1 gene correlates with the increase in the level of the mature SREBP2 in the nucleus}

To test whether the action of quercetin in the upregulation of PON1 gene was mediated via a corresponding increase in the active form of the transcription factor, SREBP2, we determined the mature SREBP2 protein $(65-\mathrm{kd}$ species) level in the nucleus of $\mathrm{HuH} 7$ cells as a function of quercetin concentration in the incubation medium. As shown in Fig. 3, incubation of $\mathrm{HuH7}$ cells for 24 hours with increasing concentration of quercetin resulted in a dosedependent 1.5 -fold $(P<.01)$ and 2.0 -fold $(P<.05)$ increase in SREBP2 in the nuclear extracts as evidenced by Western blot for the mature form of SREBP2.

\subsection{Quercetin increases the translocation of SREBP2 from ER to nucleus}

To confirm the results in Fig. 3 above, we carried out the immunostaining of the control and 24-hour quercetintreated HuH7 cells for SREBP2 along with TOPRO (for staining the nuclei) and analyzed by confocal microscopy. It is obvious from confocal images that the intensity of the SREBP2 band was negligible in the nuclei of control $\mathrm{HuH} 7$ cells that were not exposed to quercetin (Fig. 4A), whereas

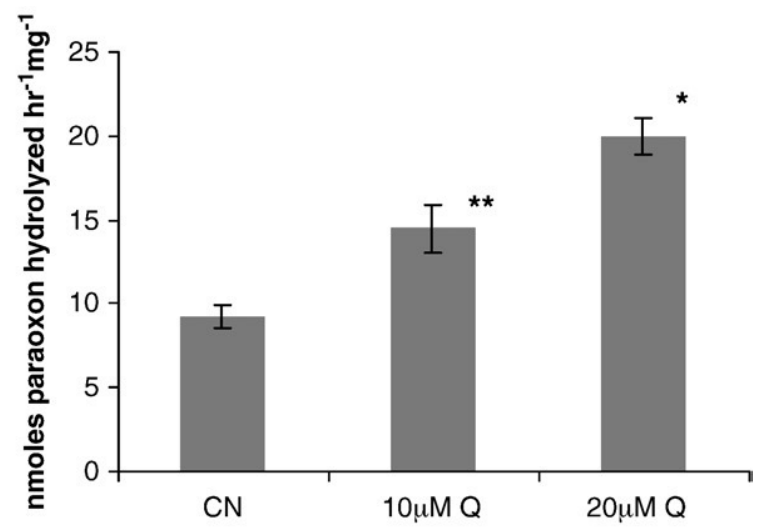

A
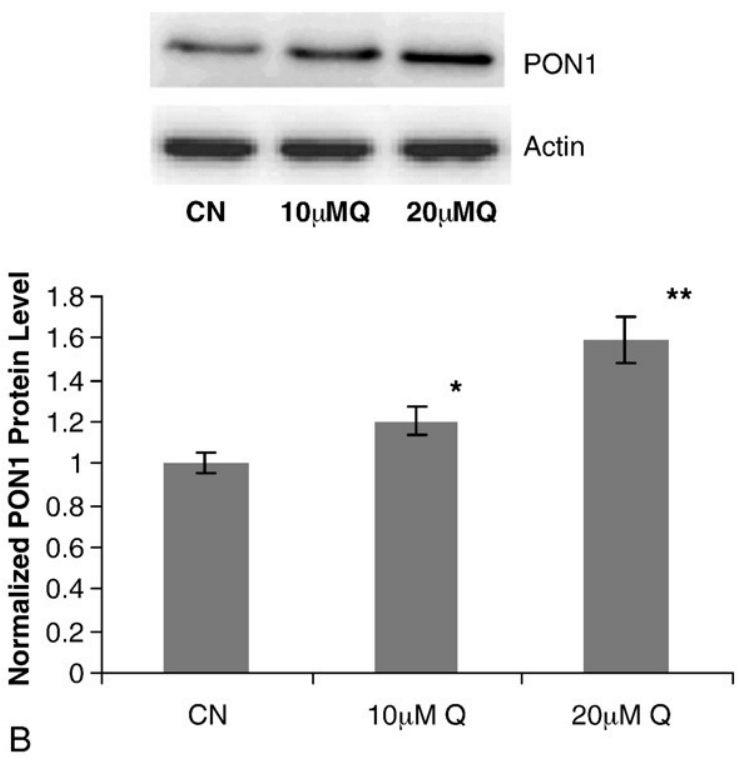

Fig. 1. A, Effect of quercetin concentrations on PON1 activity in HuH7 liver cells. $\mathrm{HuH} 7$ cells were incubated with the solvent vehicle alone (DMSO, $0.1 \% \mathrm{vol} / \mathrm{vol})$ or with 10 and $20 \mu \mathrm{mol} / \mathrm{L}$ of quercetin (10 and $20 \mu \mathrm{mol} / \mathrm{L} \mathrm{Q})$ for 48 hours. The PON1 activity in the cells was measured as described in "Experimental procedures." Analyses were performed in triplicate, and each bar represents the mean $\pm \mathrm{SD}$ of 3 samples in each group. The $P$ values of statistical significance were at $* P<.02$ and ${ }^{* *} P<.05$ levels. B, Effect of quercetin concentrations on PON1 protein in $\mathrm{HuH} 7$ liver cells. The cell extracts from the various groups were resolved on sodium dodecyl sulfate PAGE, and anti-PON1 and anti- $\beta$-actin (housekeeping gene) were used to quantify the PON1 and $\beta$-actin proteins by Western blots as described in "Experimental procedures.". The PON1 level was normalized to the $\beta$-actin protein for each sample. Analyses were performed in triplicate, and each bar represents the mean $\pm \mathrm{SD}$ of 3 samples in each group. The $P$ values of statistical significance were at $* P<.02$ and $* * P<.01$ levels.

the intensity of SREBP2 in the nuclei of cells exposed to quercetin was dramatically increased (Fig. 4B).

\subsection{Nuclear SREBP2 from HuH7 cells interact directly with PON1 SRE-like sequences}

In an attempt to conclusively prove that SREBP2 was involved in the quercetin-mediated up-regulation of PON1 


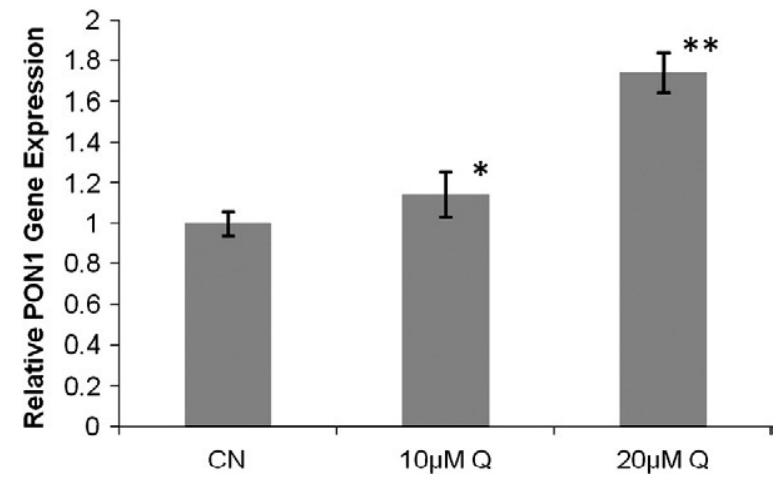

Fig. 2. Effect of quercetin concentrations on PON1 mRNA expression in $\mathrm{HuH} 7$ liver cells. The cells were incubated with the solvent vehicle DMSO alone $(0.1 \% \mathrm{vol} / \mathrm{vol})$ or with indicated concentrations of quercetin for 48 hours. The RNA extracted from each set of cells was reverse transcribed and used in the real-time PCR analyses of PON1 mRNA or $\beta$-actin mRNA using gene-specific primers as described in "Experimental procedures." The PON1 mRNA level was normalized to the level of the $\beta$-actin mRNA for each sample. Analyses were performed in triplicate, and each bar represents the mean $\pm \mathrm{SD}$ of 3 samples in each group. The $P$ values of statistical significance were at $* P<.05$ and $* * P<.02$ levels.

promoter and that this up-regulation was indeed SRE dependent, we performed EMSA with the SRE-like element 5'-ATCAAGCTAC-3' ( -392 to $-382 \mathrm{bp}$ ). The SRE core element $5^{\prime}$-ATCACCCCAC-3' was used as the positive control. Binding assay was carried out by EMSA using the nuclear extracts from 24 -hour quercetin $(20 \mu \mathrm{mol} / \mathrm{L})$-treated $\mathrm{HuH} 7$ cells with biotin-labeled SRE-like element and biotinlabeled SRE core sequence. As shown in Fig. 5, the oligoprotein complex band (corresponding to the arrow) was clearly observed with both SRE core sequence (lane 1) and SRE-like sequence (lane 2). In contrast, when the nuclear extract was first incubated with anti-SREBP2 antibody, the oligo-protein complex band was completely abolished (lane 3 ), indicating that the protein that formed the oligo-protein complex band with the core SRE or SRE-like sequences indeed was SREBP2. Furthermore, when the same binding assay was carried out with 200-fold molar excess of unlabeled SRE-like sequence, the intensity of the DNAprotein complex band was enormously decreased (lane 4), indicating that SREBP2 specifically interacted with core SRE and SRE-like sequence on the PON1 promoter.

\section{Discussion}

Quercetin, a polyphenol commonly found in fruits and vegetables, has been proven to possess antioxidative properties [17,18]; and we have recently demonstrated that quercetin feeding in both rats and $\mathrm{LDLR}^{-/}$mice upregulated liver PON1 gene and activity with concomitant protective capacity of high-density lipoprotein against LDL oxidation [20]. Our present study demonstrating that quercetin significantly up-regulates PON1 activity, PON1 protein level, as well as PON1 mRNA expression in a dose- dependent manner in $\mathrm{HuH7}$ cells fully supports this concept. It should be pointed out that the $\mathrm{HuH7}$ cells used in this study have the RQ192 isoform of PON1 that is known to exhibit moderate activity with respect to paraoxon as the substrate [21]. However, we have previously shown that moderate ethanol up-regulates PON1 activity regardless of whether it is low- or high-activity allele [5]. It would be interesting to test whether or not quercetin also up-regulates PON1 in different liver cell lines having exclusively the specific RR192 or QQ192 or RQ192 isoform.

The PON1 gene is reported to be regulated by Sp1 and protein kinase $\mathrm{C}$ (PKC) $\alpha$ or $\zeta$, which interacts with the consensus Sp1 binding site in PON1 promoter -111 to $-95 \mathrm{bp}$ upstream of transcription initiation site. Overexpression of Sp1 dramatically enhanced PON1 promoter activity. However, overexpression of PKC significantly reduced PON1 promoter activity [23].

Previously, statins have been reported to up-regulate PON1 gene via the interaction of SREBP2 with Sp1 site [12]. In contrast, others reported opposite effects of statins on the PON1 gene regulation [14], implying that the action of statins in the regulation of PON1 gene may be controversial. A subsequent report [15] further complicated the confusion in PON1 gene regulation by implying that dietary polyphenols up-regulate PON1 gene expression via aryl hydrocarbon receptor-dependent mechanism, whereas a more recent study has implicated the role of peroxisome proliferator-activated receptor- $\gamma$ pathway in the regulation of PON1 expression by pomegranate polyphenols [16].
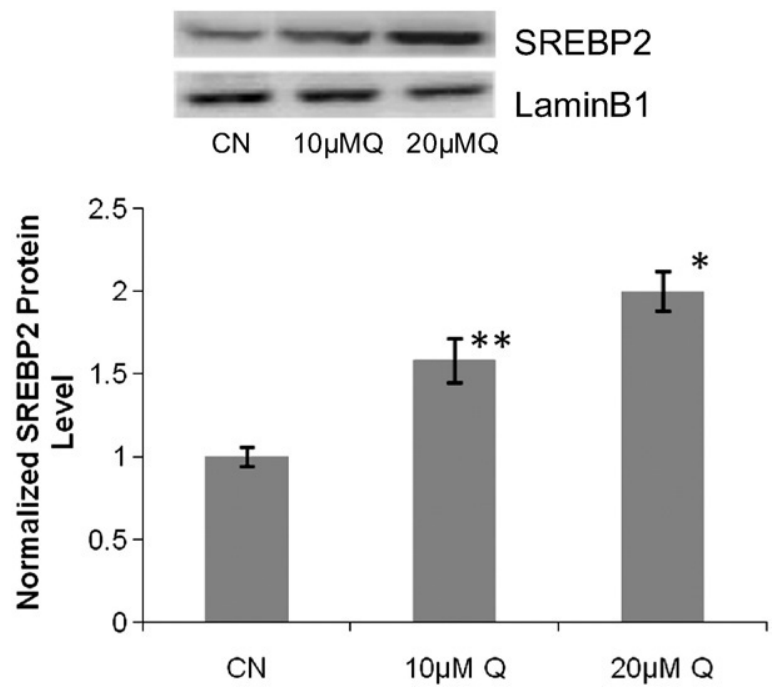

Fig. 3. Effect of quercetin concentrations on nuclear mature form of SREBP2 in HuH7 liver cells. Nuclear proteins from quercetin treated (24 h) and control cells were resolved on sodium dodecyl sulfate PAGE, and antiSREBP2 and anti-LaminB1 (housekeeping gene) were used to quantify the mature SREBP2 and LaminB1 by Western blots as described in "Experimental procedures." The SREBP2 level was normalized to the level of LaminB1 for each sample. Analyses were performed in triplicate, and each bar represents the mean $\pm \mathrm{SD}$ of 3 samples in each group. The $P$ values of statistical significance were at $* P<.01$ and $* * P<.05$ levels. $C N$ indicates control. 

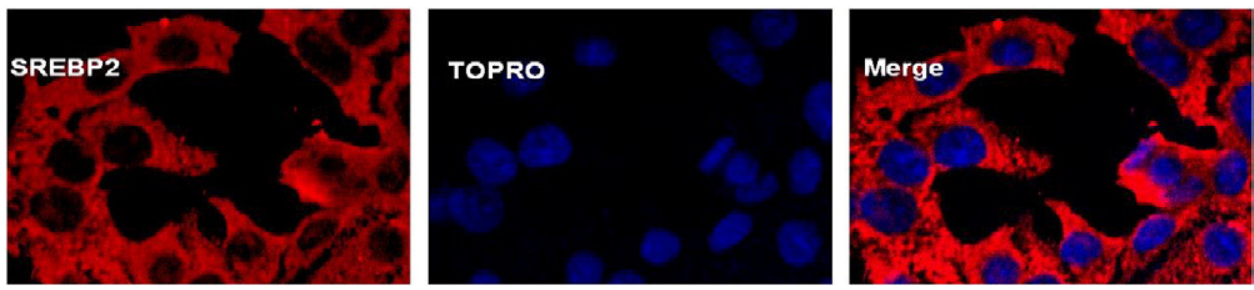

A
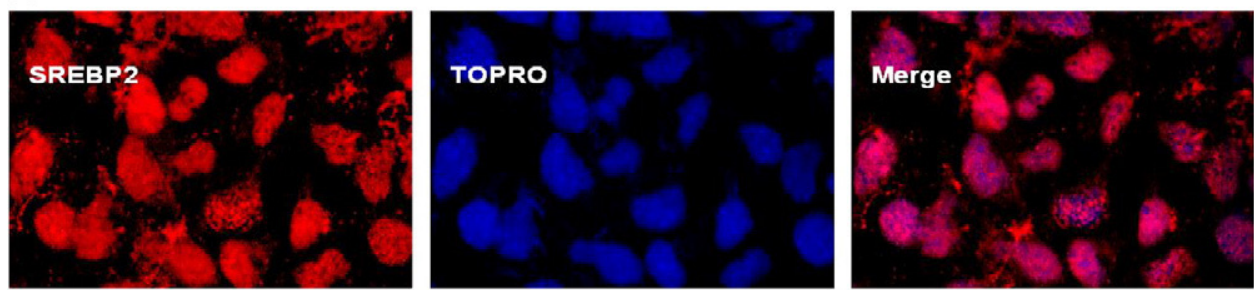

B

Fig. 4. Nuclear translocation of mature SREBP2. HuH7 cells were incubated with the solvent vehicle alone (DMSO, $0.1 \% \mathrm{vol} / \mathrm{vol}$ ) or with $20 \mu \mathrm{mol} / \mathrm{L}$ quercetin for 24 hours, after which they were immunostained with anti-SREBP2 antibody and TOPRO to stain the nuclei and analyzed by confocal microscopy as described in "Experimental procedures." A, Confocal image of control cells. B, Confocal image of quercetin-treated cells.

Our data (Fig. 3) demonstrating corresponding increase in nuclear SREBP2 in quercetin-exposed cells strongly support the possibility that, besides the $\mathrm{Sp} 1$ and PKC interaction mechanism, quercetin-mediated up-regulation of PON1 gene could also be exerted via SREBP2. The definitive role of SREBP2 in the quercetin-induced up-regulation of PON1 is confirmed by the corresponding translocation of mature SREBP2 (65-kd fragment) into the nucleus from the inactive 125 -kd fragment in the ER by confocal microscopy (Fig. 4). Interestingly, SREBP2 has been shown to be involved in soy isoflavones-mediated up-regulation of LDL receptor in HepG2 cells [13]. Work is currently in progress to test whether quercetin is directly involved in this

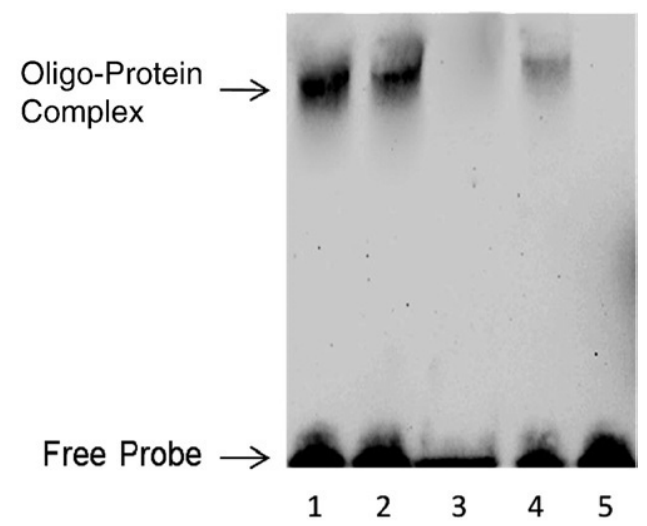

Fig. 5. The EMSA analyses were performed to quantify the binding of SREBP2 from the nuclear extract of 24-hour quercetin $(20 \mu \mathrm{mol} / \mathrm{L})$-treated $\mathrm{HuH} 7$ cells to the SRE-like sequence present in PON1 promoter and the SRE core sequence as described in "Experimental procedures." Lane 1, labeled SRE core sequence of PON1 promoter + nuclear extract; lane 2, labeled SRE-like sequence + nuclear extract; lane 3, labeled SRE sequence + nuclear extract + anti-SREBP2 antibody; lane 4, labeled SRE sequence + nuclear extract +200 -fold molar excess of unlabeled SRE sequence; lane 5, labeled binding reaction with no nuclear protein. translocation of SREBP2 from ER to nucleus or via alteration in cellular cholesterol.

Sterol regulatory element binding protein 2 interacts with sterol responsive/regulatory element (SRE) or E-box present in the promoters of target genes to regulate their expression. The 1.8-kilobase PON1 promoter sequence was systematically analyzed, and several SRE and E-box consensus sequences sites were found in the promoter region. The fact that quercetin-mediated up-regulation of PON1 mRNA correlated very well with the corresponding increase in the mature SREBP 2 in the nuclear fraction of $\mathrm{HuH} 7$ cells strongly supports the concept that the action of quercetin is mediated through the mature SREBP2. That the mature SREBP2 binds to PON1 promoter in an SRE-dependent manner and upregulates PON1 gene is strongly supported by our demonstration that mature SREBP2 from the nuclear extract binds to SRE-like sequence in the PON1 promoter that is abolished by anti-SREBP2 as well by excess SRE sequence (Fig. 5).

We therefore conclude that quercetin exhibits its antiatherogenic property by eliciting the translocation of the mature SREBP2 from ER to the nucleus, which binds to SRE-like sequence in the PON1 promoter and up-regulates PON1 gene transcription and PON1 activity.

\section{Acknowledgment}

This work was supported partially by a VA Merit Review grant from the Department of Veterans Affairs (Raj Lakshman) and an R21 grant from the National Institutes of Health (Raj Lakshman).

\section{References}

[1] Aldridge WN. Serum esterase II: an enzyme hydrolyzing diethyl $p$-nitrophenyl phosphate (E600) and its identity with the A-esterase of mammalian sera. Biochem J 1953;53:117-24. 
[2] Blatter MC, James RW, Messmer S, Barja F, Pometta D. Identification of a distinct human high-density lipoprotein subspecies defined by a lipoprotein-associated protein, K-45. Identity of K-45 with paraoxonase. Eur J Biochem 1993;211:871-9.

[3] Mackness MI, Abbott C, Arrol S, Durrington PN. The role of highdensity lipoprotein and lipid-soluble antioxidant vitamins in inhibiting low-density lipoprotein oxidation. Biochem J 1993;294 (Pt 3):829-34.

[4] Watson AD, Berliner JA, Hama SY, La Du BN, Faull KF, Fogelman AM, et al. Protective effect of high density lipoprotein associated paraoxonase. Inhibition of the biological activity of minimally oxidized low density lipoprotein. J Clin Invest 1995;96: 2882-91.

[5] Rao MN, Marmillot P, Gong M, Palmer DA, Seeff LB, Strader DB, et al. Light, but not heavy alcohol drinking, stimulates paraoxonase by upregulating liver mRNA in rats and humans. Metabolism 2003;52:1287-94

[6] Aviram M, Rosenblat M. Paraoxonases 1, 2, and 3, oxidative stress, and macrophage foam cell formation during atherosclerosis development. Free Radic Biol Med 2004;37:1304-16.

[7] Mackness MI, Arrol S, Abbott CA, Durrington PN. Is paraoxonase related to atherosclerosis. Chem Biol Interact 1993;87:161-71.

[8] Jakubowski H, Zhang L, Bardeguez A, Aviv A. Homocysteine thiolactone and protein homocysteinylation in human endothelial cells: implications for atherosclerosis. Circ Res 2000;87:45-51.

[9] Shih DM, Gu L, Xia YR, Navab M, Li WF, Hama S, et al. Mice lacking serum paraoxonase are susceptible to organophosphate toxicity and atherosclerosis. Nature 1998;394:284-7.

[10] Mackness M, Durrington P, Mackness B. Paraoxonase 1 activity, concentration and genotype in cardiovascular disease. Curr Opin Lipidol 2004;15:399-404.

[11] Horton JD, Goldstein JL, Brown MS. SREBPs: activators of the complete program of cholesterol and fatty acid synthesis in the liver. J Clin Invest 2002;109:1125-31.

[12] Deakin S, Leviev I, Guernier S, James RW. Simvastatin modulates expression of the PON1 gene and increases serum paraoxonase: a role for sterol regulatory element-binding protein-2. Arterioscler Thromb Vasc Biol 2003;23:2083-9.
[13] Mullen E, Brown RM, Osborne TF, Shay NF. Soy isoflavones affect sterol regulatory element binding proteins (SREBPs) and SREBPregulated genes in HepG2 cells. J Nutr 2004;134:2942-7.

[14] Gouedard C, Koum-Besson N, Barouki R, Morel Y. Opposite regulation of the human paraoxonase-1 gene PON-1 by fenofibrate and statins. Mol Pharmacol 2003;63:945-56.

[15] Gouedard C, Barouki R, Morel Y. Dietary polyphenols increase paraoxonase 1 gene expression by an aryl hydrocarbon receptordependent mechanism. Mol Cell Biol 2004;24:5209-22.

[16] Khateeb J, Gantman A, Kreitenberg AJ, Aviram M, Fuhrman B. Paraoxonase 1 (PON1) expression is hepatocytes is upregulated by pomegranate polyphenols: a role for PPAR-gamma pathway.

[17] Hayek T, Fuhrman B, Vaya J, Rosenblat M, Belinky P, Coleman R, et al. Reduced progression of atherosclerosis in apoprotein $\mathrm{E}$-deficient mice following consumption of red wine, or its polyphenols quercetin or catechin, is associated with reduced susceptibility of LDL to oxidation and aggregation. Arterioscler Thromb Vasc Biol 1997;17:2744-52.

[18] De Whalley CV, Rankin SM, Hoult JR, Jessup W, Leake DS Flavonoids inhibit the antioxidative modification of low density lipoproteins. Biochem Pharmacol 1990;39:1743-9.

[19] Hollman PC, Hertgo MG, Katan MB. Role of dietary flavonoids in protection against cancer and coronary heart disease. Biochem Soc Trans 1996;24:785-9.

[20] Gong M, Garige M, Varatharajalu R, Marmillot P, Gottipatti C, Leckey LC, et al. Quercetin up-regulates paraoxonase 1 gene expression with concomitant protection against LDL oxidation. Biochem Biophys Res Communication 2009;379:1001-4

[21] Humbert R, Adler DA, Disteche CM, et al. The molecular basis of the human serum paraoxonase activity polymorphism. Nat Genet 1993;3:73-6.

[22] Garin MC, James RW, Dussoix P, et al. Paraoxonase polymorphism Met-Leu54 is associated with modified serum concentrations of the enzyme. A possible link between the paraoxonase gene and increased risk of cardiovascular disease in diabetes. J Clin Invest 1997;99:62-6.

[23] Osaki F, Ikeda Y, Suehiro T, Ota K, Tsuzura S, Arii K, et al. Roles of $\mathrm{Sp} 1$ and protein kinase $\mathrm{C}$ in regulation of human serum paraoxonase 1 (PON1) gene transcription in HepG2 cells. Atherosclerosis 2004;176: 279-87. 